\title{
Protective Face Mask Filter Capable of Inactivating SARS-CoV-2, and Methicillin-Resistant Staphylococcus aureus and Staphylococcus epidermidis
}

\author{
Miguel Martí ${ }^{1,+} \oplus$, Alberto Tuñón-Molina ${ }^{1,+}+\infty$, Finn Lillelund Aachmann ${ }^{2}\left(\mathbb{0}\right.$, Yukiko Muramoto $^{3}$, Takeshi Noda ${ }^{3}$, \\ Kazuo Takayama ${ }^{4, *(D)}$ and Ángel Serrano-Aroca ${ }^{1, * \mathbb{D}}$ \\ 1 Biomaterials and Bioengineering Lab, Centro de Investigación Traslacional San Alberto Magno, \\ Universidad Católica de Valencia San Vicente Mártir, c/Guillem de Castro 94, 46001 Valencia, Spain; \\ miguel.marti@ucv.es (M.M.); alberto.tunon@ucv.es (A.T.-M.) \\ 2 The Norwegian Biopolymer Laboratory (NOBIPOL), Department of Biotechnology and Food Science, \\ NTNU Norwegian University of Science and Technology, Sem Sælands vei6-8, N-7491 Trondheim, Norway; \\ finn.l.aachmann@ntnu.no \\ 3 Laboratory of Ultrastructural Virology, Institute for Frontier Life and Medical Sciences, Kyoto University, \\ Kyoto 606-8507, Japan; muramo@infront.kyoto-u.ac.jp (Y.M.); t-noda@infront.kyoto-u.ac.jp (T.N.) \\ 4 Center for iPS Cell Research and Application, Kyoto University, Kyoto 606-8397, Japan \\ * Correspondence: kazuo.takayama@cira.kyoto-u.ac.jp (K.T.); angel.serrano@ucv.es (Á.S.-A.) \\ + These authors contributed equally to this work.
}

Citation: Martí, M.; Tuñón-Molina A.; Aachmann, F.L.; Muramoto, Y.; Noda, T.; Takayama, K.; SerranoAroca, Á. Protective Face Mask Filter Capable of Inactivating SARS-CoV-2, and Methicillin-Resistant Staphylococcus aureus and Staphylococcus epidermidis. Polymers 2021, 13, 207. https://doi.org/ $10.3390 /$ polym 13020207

Received: 19 December 2020

Accepted: 6 January 2021

Published: 8 January 2021

Publisher's Note: MDPI stays neutral with regard to jurisdictional clai$\mathrm{ms}$ in published maps and institutional affiliations.

Copyright: (C) 2021 by the authors. Licensee MDPI, Basel, Switzerland. This article is an open access article distributed under the terms and conditions of the Creative Commons Attribution (CC BY) license (https:// creativecommons.org/licenses/by/ $4.0 /)$.

\begin{abstract}
Face masks have globally been accepted to be an effective protective tool to prevent bacterial and viral transmission, especially against indoor aerosol transmission. However, commercial face masks contain filters that are made of materials that are not capable of inactivating either SARS-CoV-2 or multidrug-resistant bacteria. Therefore, symptomatic and asymptomatic individuals can infect other people even if they wear them because some viable viral or bacterial loads can escape from the masks. Furthermore, viral or bacterial contact transmission can occur after touching the mask, which constitutes an increasing source of contaminated biological waste. Additionally, bacterial pathogens contribute to the SARS-CoV-2-mediated pneumonia disease complex, and their resistance to antibiotics in pneumonia treatment is increasing at an alarming rate. In this regard, herein, we report the development of a non-woven face mask filter fabricated with a biofunctional coating of benzalkonium chloride that is capable of inactivating more than $99 \%$ of SARS-CoV-2 particles in one minute of contact, and the life-threatening methicillin-resistant Staphylococcus aureus and Staphylococcus epidermidis (normalized antibacterial halos of $0.52 \pm 0.04$ and $0.72 \pm 0.04$, respectively). Nonetheless, despite the results obtained, further studies are needed to ensure the safety and correct use of this technology for the mass production and commercialization of this broad-spectrum antimicrobial face mask filter. Our novel protective non-woven face mask filter would be useful for many healthcare workers and researchers working in this urgent and challenging field.
\end{abstract}

Keywords: SARS-CoV-2; MRSA; MRSE; face mask filter; benzalkonium chloride; COVID-19; multidrug-resistant bacteria

\section{Introduction}

The severe acute respiratory syndrome coronavirus 2 (SARS-CoV-2) was first reported in Wuhan, Hubei province, China, in December 2019 [1]. The rapid spread of this pathogen, which has caused the current COVID-19 pandemic, is putting at high risk the health and economy of the most developed and underdeveloped countries. According to the World Health Organization (WHO), the current COVID-19 outbreak has 83,979,200 global cases and 1,827,796 global deaths in more than 200 countries (data as of 2 January 2021) [2]. SARS-CoV-2 is the third coronavirus causing severe pneumonia [3,4], an infection of the lungs usually caused by bacteria and viruses $[5,6]$. The death risk of viral pneumonias 
can increase when co-infection can be caused by viruses in the setting of communityacquired bacterial pneumonia such as the lethal Streptococcus pneumoniae [7-10], with additional symptoms of bacterial pneumonia [11]. New pathogens, such as SARS-CoV2 , which can coexist with a broad range of other types of clinically relevant bacteria, including multidrug-resistant strains, constitute a real-life threat to humans. In addition, antibiotic resistance in bacterial pneumonia treatment is a widespread problem that is increasing at an alarming rate $[12,13]$. The SARS-CoV-2 pathogen is stable from hours to days in aerosols and surfaces of different chemical natures such as copper, cardboard, plastic, aluminum or stainless steel surfaces, demonstrating that infections can be easily transmitted through the air via microdroplets or direct contact after touching contaminated surfaces [14-18]. This coronavirus can spread faster than its two ancestors SARS-CoV and MERS-CoV [19] through coughing, sneezing, touching or breathing [20], and more broadly through asymptomatic carriers [21-23]. Recent studies have demonstrated that direct indoor aerosol transmission or ventilation systems can potentially transmit SARSCoV-2 [24-26]. Although the confinements conducted in many countries flattened the epidemic curve before the hot season $[27,28]$, SARS-CoV-2 continues to spread globally.

SARS-CoV-2 is an enveloped, positive-sense, single-stranded RNA virus [29] that belongs to Baltimore group IV [30]. Other enveloped RNA viruses such as influenza A (H1N1) can be inactivated by quaternary ammonium compounds such as benzalkonium chloride (BAK) [31]. It has been recently remarked, however, that further evaluation of the effectiveness of BAK against coronaviruses is needed [32] because the Centers for Disease Control and Prevention have reported that available evidence indicates BAK has less reliable activity against certain bacteria and viruses than either of the alcohols [33]. However, a recent report has shown the in vitro virucidal activity of ethanol $(70 \%)$, povidone-iodine $(7.5 \%)$, chloroxylenol $(0.05 \%)$, chlorhexidine $(0.05 \%)$ or benzalkonium chloride $(0.1 \%)$ was similar when used as disinfectants against SARS-CoV-2 [18]. Thus, the oral rinse Dequonal, which contains BAK, has shown virucidal activity against SARS-CoV-2 under conditions mimicking nasopharyngeal secretions to support the idea that oral rinsing might reduce the viral load of saliva and could thus lower the transmission of SARS-CoV-2 [34]. Furthermore, very recently, a preprint reported an oil-in-water nanoemulsion formulation containing $0.13 \%$ BAK that has demonstrated safe and broad antiviral activity against enveloped viruses such as SARS-CoV-2, human coronavirus, respiratory syncytial virus and influenza $B$ [35]. In that study, the repeated application of this BAK-containing nanoemulsion, twice daily for 2 weeks onto rabbit nostrils indicated safety with no irritation. In fact, this chemical compound is widely used as a disinfectant against bacteria, viruses, pathogenic fungi and mycobacteria, and it has been approved by the Food and Drug Administration as a skin disinfectant [36].

Face masks have been accepted as effective protective tools by blocking the pass of viral and bacterial particles [37]. However, if the filters that contain the face masks are made of composite materials with antimicrobial activity, the protection of these tools could increase even more. Thus, several antiviral face mask materials against SARS-CoV-2 have been recently proposed. However, all of these studies, some of them not peer-reviewed yet, propose expensive materials such as graphene [38], copper [39] or silver [40]. These antiviral composites are produced with complex and costly manufacturing processes, which render them non-viable for a global solution of the current COVID-19 pandemic strongly affecting both developed and underdeveloped countries. In this regard, we hypothesize here that the physical adsorption of BAK via the dip coating method [41] onto the surface of a commercial non-woven fabric filter, which is commonly used in the production of face masks in the present pandemic, could produce a low-cost antiviral filter that could inhibit the infection capacity of SARS-CoV-2. Non-woven filters are lightweight, flexible, resilient, provide good bacteria filtration and air permeability, are cost-effective materials for masks, have a lower manufacturing cost and are hygienic and clean as they are for single use [42]. Furthermore, due to the previously reported antibacterial activity of BAK against Gram-positive bacteria [43], we also expect that the developed BAK filter 
will be able to inhibit the bacterial growth of two clinically relevant multidrug-resistant bacteria: methicillin-resistant Staphylococcus aureus (MRSA) and Staphylococcus epidermidis (MRSE). In addition to the current COVID-19 pandemic, antibiotic resistance is another increasing challenge of the present century. According to the World Health Organization (WHO), antibiotic resistance will be one of the leading causes of death over other important diseases such as cancer by the year 2050 [44]. In fact, MRSE is a nosocomial pathogen that is spreading globally and is often the cause of catheter-associated disease, especially among low-birth-weight premature infants $[45,46]$. MRSA is causing global health problems, especially in medical instruments and catheters because $S$. aureus is a human pathogen that can easily develop resistance to antibiotics $[47,48]$. Therefore, in this study, we attempted to develop a low-cost protective face mask filter capable of inactivating SARS-CoV-2, and MRSA and MRSE.

\section{Materials and Methods}

\subsection{Dip Coating of Commercial Face Filter Masks}

Disks specimens of approximately $10 \mathrm{~mm}$ in diameter were prepared with a nonwoven spunlace fabric filter (commercial filters used for face masks, NV EVOLUTIA, Valencia, Spain) by dry-cutting with a cylindrical punch. Face mask filter (BAK filter) disks $(n=6)$ were produced by the dip coating method [41] using commercial $70 \%$ ethyl alcohol with $0.1 \% w / w$ benzalkonium chloride (Montplet, Barcelona, Spain) for $1 \mathrm{~min}$ at $25{ }^{\circ} \mathrm{C}$ to achieve a dry BAK content, determined gravimetrically, of $0.46 \pm 0.13 \% w / w$. Another face mask filter (S filter) disk $(n=6)$ was subjected to the same dip coating treatment but using only an absolute ethanol/distilled water solution $(70 / 30 \% v / v)$ without BAK for $1 \mathrm{~min}$ at $25{ }^{\circ} \mathrm{C}$. Untreated face mask filter (U filter) disks $(n=6)$ were produced as reference material. The disks were subsequently dried at $60^{\circ} \mathrm{C}$ for $48 \mathrm{~h}$ to constant weight and sterilized by UV radiation (TELSTAR Technologies S.L, Terrassa, Spain) for one hour per each side.

\subsection{Characterization of the Benzalkonium Chloride}

Nuclear magnetic resonance (NMR) was applied for the characterization of the benzalkonium chloride used in the biofunctional coating of the commercial non-woven filter. Prior to NMR sample preparation, the ethanol/water solvent was evaporated from commercial Montplet $70 \%$ ethyl alcohol with benzalkonium chloride $(99.9 / 0.1 \% w / w)$ at $25{ }^{\circ} \mathrm{C}$. After that, the sample of benzalkonium chloride was prepared by dissolving $10 \mathrm{mg}$ in 550 $\mu \mathrm{L} \mathrm{D}_{2} \mathrm{O}$ (D, 99.9\%) (Sigma-Aldrich, City Norway) and transferred to a $5 \mathrm{~mm}$ LabScape Stream NMR tube. The NMR experiments were recorded on a BRUKER AVIIIHD 800 $\mathrm{MHz}$ (Bruker BioSpin AG, Fälladen, Switzerland) equipped with a $5 \mathrm{~mm}$ cryogenic CP-TCI. All NMR recording was performed at $25^{\circ} \mathrm{C}$ or $37^{\circ} \mathrm{C}$. For the characterization of benzalkonium chloride the following spectra were recorded: 1D proton, 2D double quantum filtered correlation spectroscopy (DQF-COSY) and $2 \mathrm{D}^{13} \mathrm{C}$ heteronuclear single quantum coherence (HSQC) with multiplicity editing. TMS was used as a chemical shift reference for proton and carbon chemical shifts. The spectra were recorded, processed and analyzed using TopSpin 3.7 software (Bruker BioSpin AG, Fällanden, Switzerland).

\subsection{Electron Microscopy}

A Zeiss Ultra 55 field emission scanning electron microscope (FESEM, Carl Zeiss Microscopy, Jena, Germany) was operated at an accelerating voltage of $3 \mathrm{kV}$ to observe the porous morphology of the treated and untreated non-woven face mask filters at a magnification of $\times 100$ and $\times 1000$. The filter samples were prepared to be conductive by platinum coating with a sputter coating unit.

\subsection{Phage Phi 6 Host Culture}

Pseudomonas syringae (DSM 21482) from the Leibniz Institute DSMZ-German Collection of Microorganisms and Cell cultures GmbH (Braunschweig, Germany) was cultured 
in solid tryptic soy agar (TSA, Liofilchem) and subsequently in liquid tryptic soy broth (TSB, Liofilchem). Liquid incubation was carried out at $25^{\circ} \mathrm{C}$ and $120 \mathrm{rpm}$.

\subsection{Phage Phi 6 Propagation}

Phage phi 6 (DSM 21518) propagation was carried out according to the specifications provided by the Leibniz Institute DSMZ-German Collection of Microorganisms and Cell Cultures GmbH (Braunschweig, Germany).

\subsection{Antiviral Test Using the Biosafe Viral Model}

A volume of $50 \mu \mathrm{L}$ of a phage suspension in TSB was added to each filter at a titer of about $1 \times 10^{6}$ plaque-forming units per $\mathrm{mL}(\mathrm{PFU} / \mathrm{mL}$ ) and allowed to incubate for 1 , 10 and $30 \mathrm{~min}$. Each filter was placed in a falcon tube with $10 \mathrm{~mL}$ TSB and sonicated for $5 \mathrm{~min}$ at $24^{\circ} \mathrm{C}$. After that, each tube was vortexed for $1 \mathrm{~min}$. Serial dilutions of each falcon sample were made for phage titration, and $100 \mu \mathrm{L}$ of each phage dilution was contacted with $100 \mu \mathrm{L}$ of the host strain at $\mathrm{OD}_{600 \mathrm{~nm}}=0.5$. The infective capacity of the phage was measured based on the double-layer method [49], where $4 \mathrm{~mL}$ of top agar (TSB $+0.75 \%$ bacteriological agar, Scharlau) and $5 \mathrm{mM} \mathrm{CaCl}_{2}$ were added to the phage-bacteria mixture which was poured on TSA plates. The plates were incubated for $24-48 \mathrm{~h}$ in an oven at $25^{\circ} \mathrm{C}$. The phage titer of each type of sample was calculated in PFU $/ \mathrm{mL}$ and compared with the control, that is, $50 \mu \mathrm{L}$ of phage added to the bacteria without being in contact with any filter and without being sonicated. The antiviral activity in log reductions of titers was estimated at 1, 10 and $30 \mathrm{~min}$ of contact with the virus model. It was checked that the residual amounts of disinfectants in the titrated samples did not interfere with the titration process and the sonication-vortex treatment did not affect the infectious capacity of the phage. The antiviral tests were performed three times during two different days $(n=6)$ to ensure reproducibility.

\subsection{Antiviral Tests Using SARS-CoV-2}

The SARS-CoV-2 strain used in this study (SARS-CoV-2/Hu/DP/Kng/19-027) was kindly gifted to us by Dr. Tomohiko Takasaki and Dr. Jun-Ichi Sakuragi at the Kanagawa Prefectural Institute of Public Health. The virus was plaque-purified and propagated in Vero cells. SARS-CoV-2 was stored at $-80^{\circ} \mathrm{C}$.

A volume of $50 \mu \mathrm{L}$ of a virus suspension in phosphate-buffered saline (PBS) was added to each filter at a titer dose of $1.3 \times 10^{5} \mathrm{TCID} 50 /$ filter, and then incubated for $1 \mathrm{~min}$ at room temperature. Then, $1 \mathrm{~mL}$ PBS was added to each filter, and then vortexed for $5 \mathrm{~min}$. After that, each tube was vortexed for $5 \mathrm{~min}$ at room temperature.

Viral titers were determined through median tissue culture infectious dose (TCID50) assays inside a Biosafety Level 3 laboratory at Kyoto University. Briefly, TMPRSS2/Vero cells [50] (JCRB1818, JCRB Cell Bank), cultured with the minimum essential media (MEM, Sigma-Aldrich) supplemented with 5\% fetal bovine serum (FBS), $1 \%$ penicillin/ streptomycin, were seeded into 96-well plates (Thermo Fisher Scientific). Samples were serially diluted 10-fold from $10^{-1}$ to $10^{-8}$ in the culture medium. Dilutions were placed onto the TMPRSS2/Vero cells in triplicate and incubated at $37^{\circ} \mathrm{C}$ for $96 \mathrm{~h}$. Cytopathic effect was evaluated under a microscope. TCID50/mL was calculated using the Reed-Muench method.

\subsection{Antibacterial Tests}

The agar disk diffusion tests were performed to analyze the antibacterial activity of the treated and untreated filters [51,52]. Lawns of methicillin-resistant Staphylococcus aureus, COL [53], and the methicillin-resistant Staphylococcus epidermidis, RP62A [54], in a concentration of about $1.5 \times 10^{8} \mathrm{CFU} / \mathrm{mL}$ in tryptic soy broth, were cultivated on trypticase soy agar plates. The sterilized disks were placed upon the lawns of bacteria to be incubated aerobically at $37^{\circ} \mathrm{C}$ for $24 \mathrm{~h}$. The antibacterial activity of the tested filter disks was expressed according to Equation (1) [51]: 


$$
n w_{\text {halo }}=\frac{\frac{d_{i z}-d}{2}}{d}
$$

where $n w_{\text {halo }}$ indicates the normalized width of the antimicrobial inhibition zone, $d_{i z}$ is the inhibition zone diameter and $d$ refers to the sample disk diameter. These diameters were measured by image software analysis (Image J, Wayne Rasband (NIH), Bethesda, MD, USA). The tests were performed six times on different days to ensure reproducibility.

\subsection{Statistical Analysis}

The statistical analyses were performed by ANOVA followed by Tukey's post hoc test $\left.{ }^{*} p>0.05,{ }^{* * *} p>0.001\right)$ on GraphPad Prism 6 software (gGraphPad Software Inc., San Diego, CA, USA).

\section{Results}

3.1. Nuclear Magnetic Resonance of Benzalkonium Chloride

The benzalkonium chloride used in this study for the treatment of the non-woven filter analyzed by NMR is shown in Figure 1.

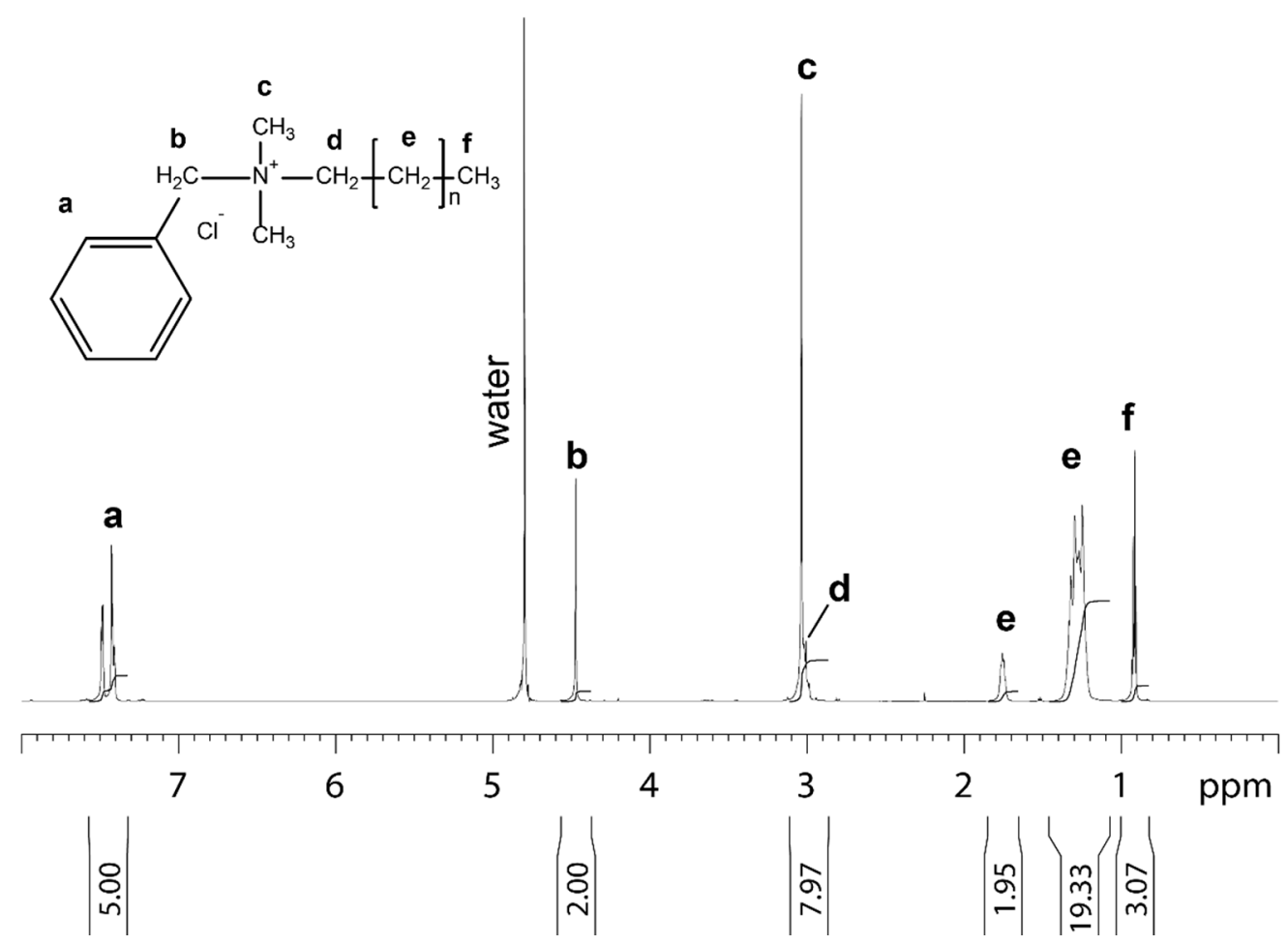

Figure 1. 1D proton NMR spectrum of benzalkonium chloride dissolved in $99.9 \% \mathrm{D}_{2} \mathrm{O}$ recorded at $25{ }^{\circ} \mathrm{C}$. Molecular structure, assignment and integral for benzalkonium chloride are shown. The letters at the molecular structure and the spectrum indicate the proton in the different chemical subgroups of benzalkonium chloride.

\subsection{Porous Morphology of the Non-Woven Face Mask Filters}

The porous morphology images of the commercial and treated non-woven face mask filter are shown in Figure 2.

FESEM observation showed no signs of porous morphological change after performing the dip coating with both ethanol-based solvent or the BAK compound. These results suggest no change of breathability or bacterial filtration efficiency required for their commercialization according to the European standard for community face coverings (CWA 17553:2020). 


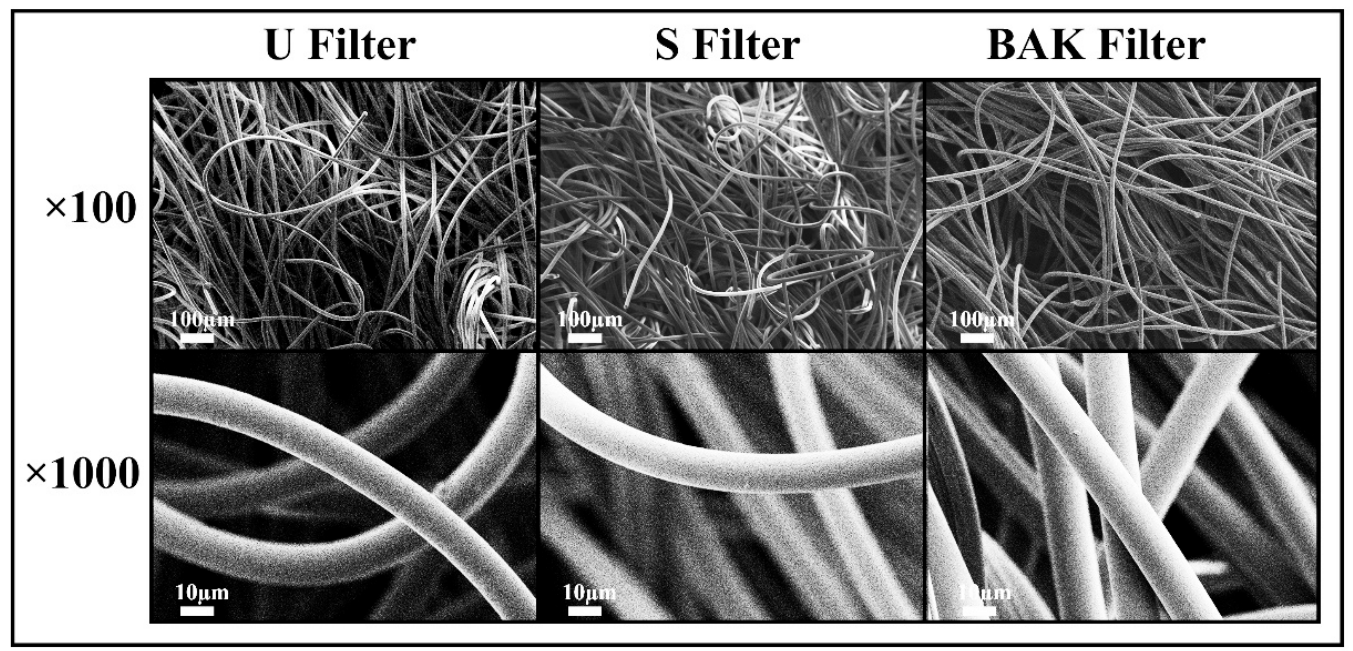

Figure 2. Morphology of the non-woven face mask filters by field emission scanning electron microscopy. Untreated filter (U filter), filter treated by dip coating with the ethanol-based solvent ( $\mathrm{S}$ filter) and filter with $0.46 \pm 0.13 \% w / w$ of biofunctional benzalkonium chloride $(\mathrm{BAK})$ coating $(\mathrm{BAK}$ filter) at two magnifications $(\times 100$ and $\times 1000)$.

\subsection{Antiviral Tests with Phage Phi 6 and SARS-CoV-2}

Phage phi 6 is a three-part, segmented, double-stranded RNA virus totaling $\sim 13.5 \mathrm{~kb}$ in length. Even though this type of lytic bacteriophage belongs to group III of the Baltimore classification [30], it was proposed here as a viral model of SARS-CoV-2, due to biosafety reasons, as it also has a lipid membrane around its nucleocapsid. Thus, the BAK Filter showed potent antiviral activity (100\% of viral inhibition, see Figures 3 and 4$)$. Bacterial lawns had clearly grown in the plate and no plaques were observed after 1, 10 or $30 \mathrm{~min}$ of contact between the BAK filter and the SARS-CoV-2 viral model. Furthermore, the U filter and $S$ filter showed similar results to control of no antiviral activity (see Figures 3 and 4).

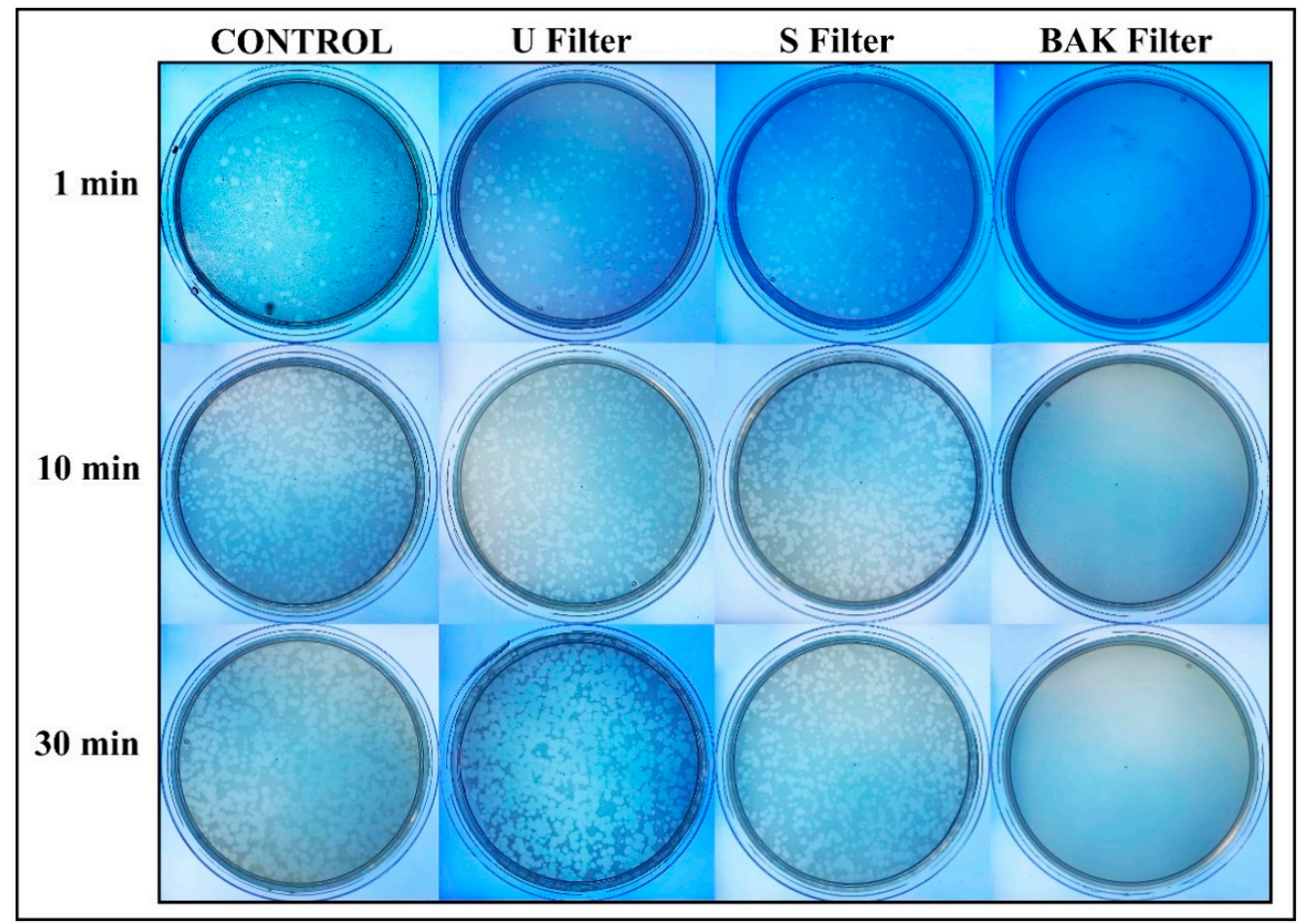

Figure 3. Loss of phage phi 6 viability measured by the double-layer method. Phage 6 titration images of undiluted samples for control, untreated filter (U filter), filter treated by dip coating with the ethanol-based solvent (S filter) and filter with the biofunctional BAK coating (BAK filter) at 1, 10 and 30 min of viral contact. 


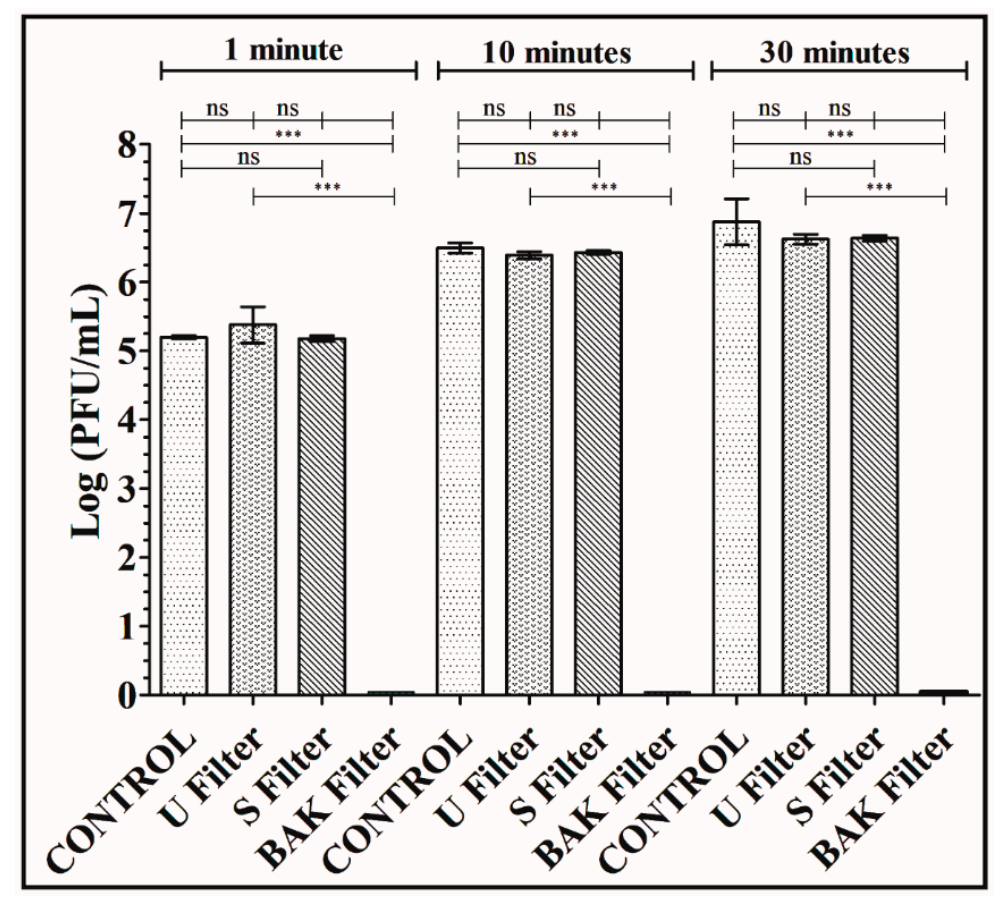

Figure 4. Titration after double-layer method with the phage phi 6 viral model. Logarithm of plaqueforming units per $\mathrm{mL}(\log (\mathrm{PFU} / \mathrm{mL}))$ of the control, untreated filter (U filter), filter treated by dip coating with the ethanol-based solvent ( $\mathrm{S}$ filter) and filter with the biofunctional BAK coating (BAK filter) at 1, 10 and 30 min of viral contact.

The phage titers of each type of face mask filter sample were calculated and compared with the control (see Figure 4).

Figure 4 shows that the titers obtained by contacting the phages with the $\mathrm{U}$ or $\mathrm{S}$ filter are similar to the control. However, the BAK filter displayed a strong phage inactivation.

The results achieved with the TCID $50 / \mathrm{mL}$ method about the reduction of infectious titers of SARS-CoV-2 after 1 min of contact with the control, the $\mathrm{U}$ filter, the $\mathrm{S}$ filter and the BAK filter containing the biofunctional coating are shown in Figure 5.

These results clearly demonstrate that the BAK filter is very effective against SARSCoV-2 even after $1 \mathrm{~min}$ of contact. This is also in good agreement with the antiviral results of the biosafe viral model used in this study (see Figures 3 and 4). The reduction of infection titers in PFU/mL determined by the double-layer assay for the phage phi 6 and by the TCID50/mL method for SARS-CoV-2 is shown in Table 1.

Table 1. Reduction of infection titers determined by the double layer assay for the phage phi 6 and via the TCID50/mL method for SARS-CoV-2. Control, untreated filter (U filter), filter treated with the ethanol solvent (S filter), filter with the biofunctional BAK coating (BAK filter).

\begin{tabular}{ccccc}
\hline Sample & $\begin{array}{c}\text { Phi 6 at 1 min } \\
\text { (PFU/mL) }\end{array}$ & $\begin{array}{c}\text { Phi 6 at 10 min } \\
\text { (PFU/mL) }\end{array}$ & $\begin{array}{c}\text { Phi 6 at 30 min } \\
\text { (PFU/mL) }\end{array}$ & $\begin{array}{c}\text { SARS-CoV-2 at 1 min } \\
\text { (PFU/mL) }\end{array}$ \\
\hline Control & $1.6 \times 10^{5} \pm 1.4 \times 10^{4}$ & $3.2 \times 10^{6} \pm 8.9 \times 10^{5}$ & $1.4 \times 10^{7} \pm 1.8 \times 10^{7}$ & $3.5 \times 10^{6} \pm 1.9 \times 10^{6}$ \\
U Filter & $3.5 \times 10^{5} \pm 3.9 \times 10^{5}$ & $2.5 \times 10^{6} \pm 5.1 \times 10^{5}$ & $4.3 \times 10^{6} \pm 1.3 \times 10^{6}$ & $3.9 \times 10^{6} \pm 1.5 \times 10^{6}$ \\
S Filter & $1.5 \times 10^{5} \pm 2.4 \times 10^{4}$ & $2.7 \times 10^{6} \pm 2.8 \times 10^{5}$ & $4.4 \times 10^{6} \pm 7.4 \times 10^{5}$ & $1.1 \times 10^{6} \pm 6.2 \times 10^{5}$ \\
BAK Filter & $0.0 \pm 0.0$ & $0.0 \pm 0.0$ & $0.0 \pm 0.0$ & $8.9 \times 10^{3} \pm 7.8 \times 10^{3}$ \\
\hline
\end{tabular}




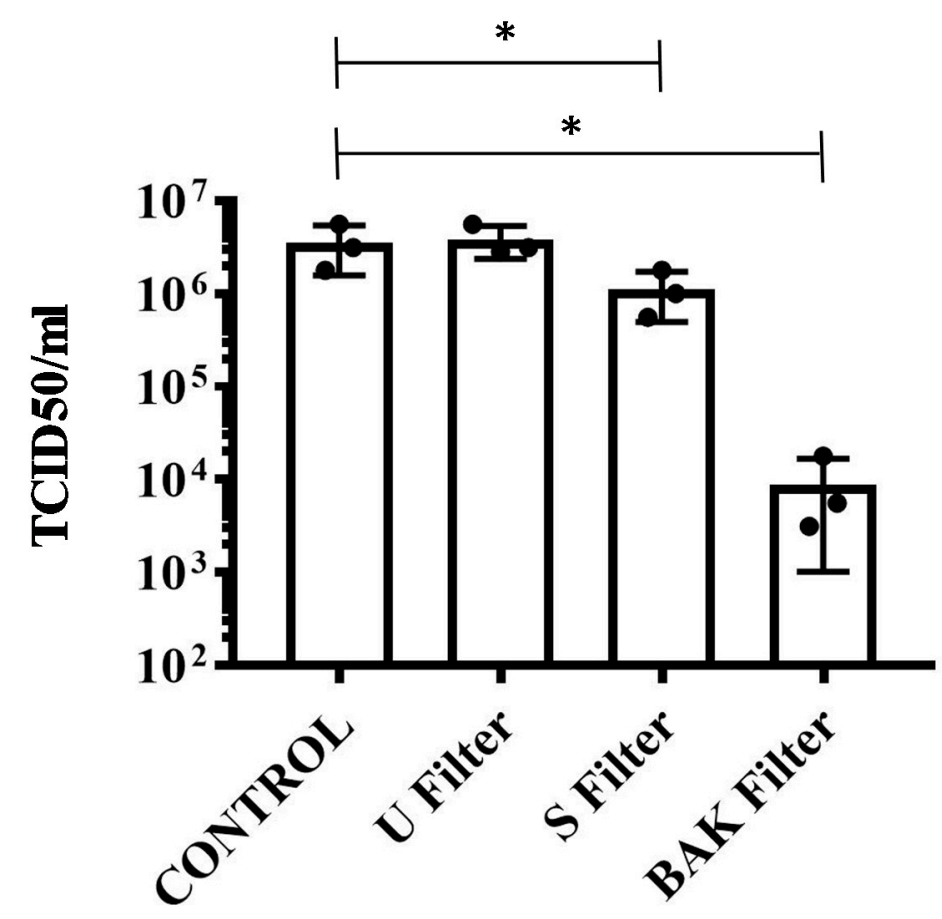

Figure 5. Reduction of infectious titers of SARS-CoV-2 after 1 min of contact. Untreated filter (U filter), filter treated with the ethanol solvent (S filter), filter with the biofunctional BAK coating (BAK filter) and control via the TCID50/mL method. A dot plot is data set based on the value of each point.

\subsection{Antibacterial Tests}

The antibacterial results of the treated and untreated filters against MRSA and MRSE multidrug-resistant bacteria are shown in Figure 6.

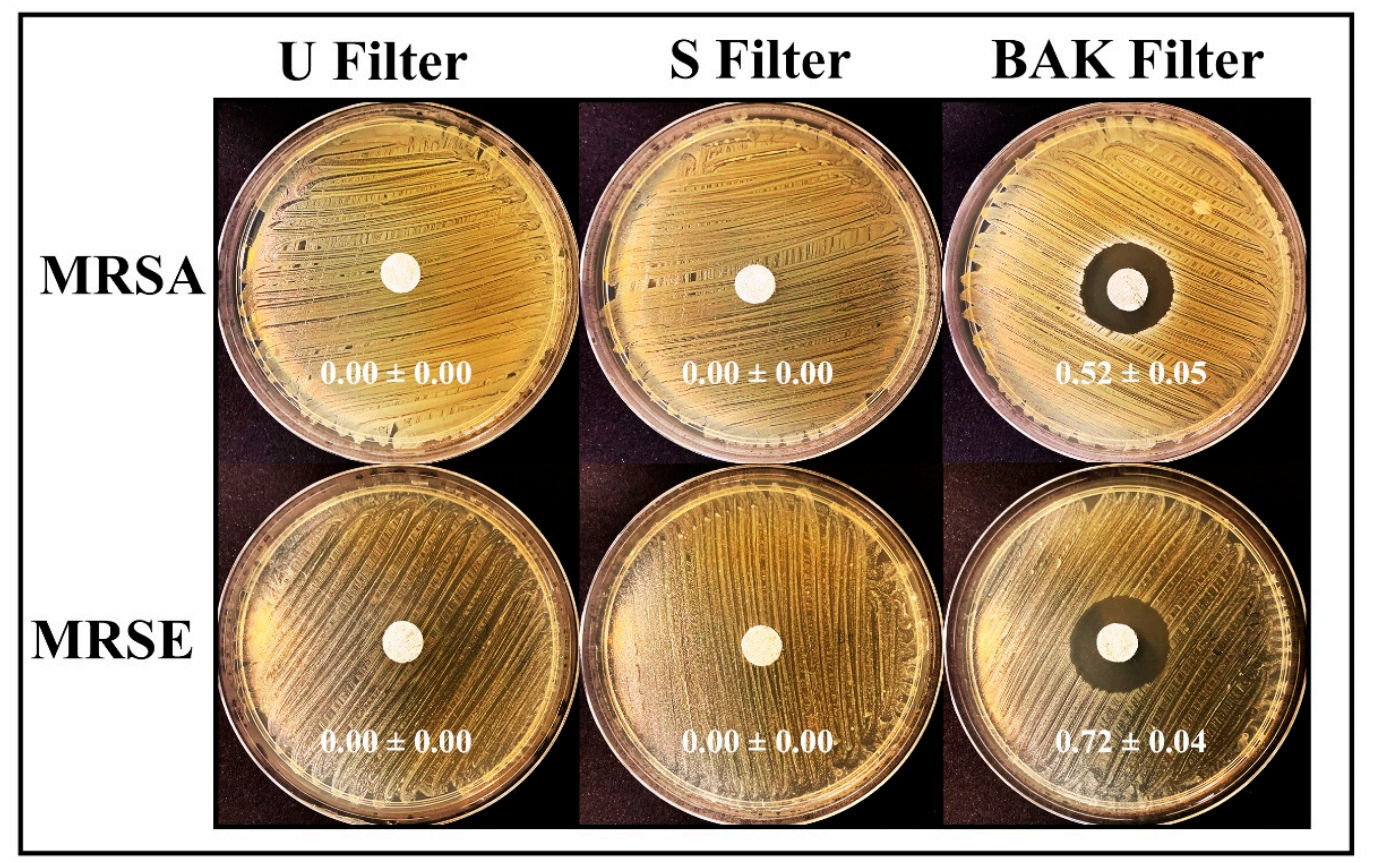

Figure 6. Antibacterial agar disk diffusion tests. Untreated filter (U filter), filter treated by dip coating with the ethanol-based solvent (S filter) and filter with the biofunctional BAK coating (BAK filter) after $24 \mathrm{~h}$ of culture at $37^{\circ} \mathrm{C}$. The normalized widths of the antibacterial halos, expressed as mean \pm standard deviation and calculated with Equation (1), are shown in each image. 
The filter treated by dip coating with $70 \%$ ethyl alcohol containing $0.1 \%$ benzalkonium chloride showed high antibacterial activity against MRSA and MRSE, being even more effective against the last strain. The antimicrobial mode of action of quaternary ammonium compounds (QACs) such as BAK against both bacterial and viral phospholipid membranes is attributed to the positively charged nitrogen atoms. This causes eradication of bacteria and common viruses such as influenza by disrupting their phospholipid bilayer membrane [32], the glycoproteinaceous envelope and the associated spike glycoproteins interacting with the ACE2 receptor in the infection of host cells [55]. For this reason, BAK is extensively found in many household disinfecting wipes and sprays and is also used as an additive in various soaps and non-alcohol-based hand sanitizers [31,56,57].

Here in this paper, a new face mask filter with antiviral and antibacterial properties against Gram-positive multidrug-resistant bacteria to reduce COVID-19 infections (from touching the filter masks and aerosol transmission in both senses) is demonstrated. This face mask filter has been developed here by dip coating (a simple, low-cost, reliable and reproducible method) a commercial non-woven filter where a thin coating of BAK was deposited onto the surface by physical adsorption [58]. The same biofunctional coating procedure could be applied to any type of face mask or biodegradable filters. This also represents a solution to the need for bio-based facemasks to counter coronavirus outbreaks [42]. The manufacturing procedure by dip coating with BAK opens up a broad range of applications that urgently demand new antimicrobial approaches. Thus, this technology may also be used for the fabrication of antimicrobial clothes, gloves, etc., for health personnel or to produce antimicrobial filters able to inactivate aerosols containing SARS-CoV-2 or Gram-positive multidrug-resistant bacteria in other applications. The antibacterial activity of this type of filter against MRSA and MRSE, and their viral inhibition capacity against SARS-CoV-2 as well as the enveloped phage phi 6 viral model demonstrates their broad antipathogenic protection.

\section{Conclusions}

This is the first report of the development of a face mask filter capable of inactivating SARS-CoV-2 and multidrug-resistant bacteria such as methicillin-resistant Staphylococcus aureus and Staphylococcus epidermidis, a new promising tool to combat the increasing COVID19 spread. This antimicrobial non-woven face mask filter was produced by a reproducible and economic procedure using benzalkonium chloride that provides excellent antiviral properties against SARS-CoV-2 ( $>99 \%$ of viral inhibition after $1 \mathrm{~min}$ of contact) and the phage phi 6 (100\% of viral inhibition after 1 min of contact), which was used here as a biosafe viral model of SARS-CoV-2. Therefore, the developed antiviral filter can be used in face masks and other protective tools, and thus is very promising to prevent the spread of SARS-CoV-2. Nonetheless, further research is required in order to ensure the safe use of the developed filters in the present COVID-19 pandemic.

Author Contributions: Conceptualization, methodology, validation and formal analysis: M.M., K.T. and Á.S.-A.; software: F.L.A., K.T. and Á.S.-A.; investigation: M.M., A.T.-M., Y.M., T.N., F.L.A., K.T. and Á.S.-A.; resources: M.M., F.L.A., K.T. and Á.S.-A.; data curation, A.T.-M., F.L.A., K.T. and Á.S.-A.; visualization: F.L.A., K.T. and Á.S.-A.; writing—original draft preparation: Á.S.-A.; writing—review and editing: M.M., A.T.-M., F.L.A., K.T. and Á.S.-A.; supervision, M.M., K.T. and Á.S.-A.; project administration, K.T. and Á.S.-A.; funding acquisition, K.T. and Á.S.-A. All authors have read and agreed to the published version of the manuscript.

Funding: This research was funded by the Fundación Universidad Católica de Valencia San Vicente Mártir, grant 2020-231-001UCV (awarded to Á.S.-A.), the Japan Agency for Medical Research and Development (AMED) (20fk0108270h0001, 20fk0108263s0201) and the Research Council of Norway through grant the Norwegian NMR platform (226244).

Institutional Review Board Statement: Not applicable.

Informed Consent Statement: Not applicable. 
Data Availability Statement: Data are contained within the article.

Acknowledgments: The authors would like to express their gratitude to the Fundación Universidad Católica de Valencia San Vicente Mártir and the Japan Agency for Medical Research and Development (AMED) for their financial support. We would like to thank Yoshio Koyanagi and Kazuya Shimura (Kyoto University) for setup and operation of the BSL-3 laboratory.

Conflicts of Interest: The authors declare no conflict of interest.

\section{References}

1. WHO. Director-General's Opening Remarks at the Media Briefing on COVID-19. Available online: https://www.who.int/dg/ speeches / detail/who-director-general-s-opening-remarks-at-the-media-briefing-on-covid-19---11-march-2020 (accessed on 11 March 2020).

2. WHO. Coronavirus Disease (COVID-19) Pandemic. Available online: https://www.who.int/emergencies/diseases/novelcoronavirus-2019 (accessed on 2 January 2021).

3. Corman, V.M.; Muth, D.; Niemeyer, D.; Drosten, C. Hosts and Sources of Endemic Human Coronaviruses. Adv. Virus Res. 2018, 100, 163-188. [PubMed]

4. Yang, X.; Yu, Y.; Xu, J.; Shu, H.; Xia, J.; Liu, H.; Wu, Y.; Zhang, L.; Yu, Z.; Fang, M.; et al. Clinical course and outcomes of critically ill patients with SARS-CoV-2 pneumonia in Wuhan, China: A single-centered, retrospective, observational study. Lancet Respir. Med. 2020, 8, 475-481. [CrossRef]

5. Shah, S.N.; Bachur, R.G.; Simel, D.L.; Neuman, M.I. Childhood pneumonia. JAMA J. Am. Med. Assoc. 2017, 318, 490. [CrossRef]

6. Brenner, D.R.; McLaughlin, J.R.; Hung, R.J. Previous lung diseases and lung cancer risk: A systematic review and meta-analysis. PLoS ONE 2011, 6, e17479. [CrossRef] [PubMed]

7. Su, I.C.; Lee, K.L.; Liu, H.Y.; Chuang, H.C.; Chen, L.Y.; Lee, Y.J. Severe community-acquired pneumonia due to Pseudomonas aeruginosa coinfection in an influenza A(H1N1)pdm09 patient. J. Microbiol. Immunol. Infect. 2019, 52, 365-366. [CrossRef] [PubMed]

8. Chou, C.C.; Shen, C.F.; Chen, S.J.; Chen, H.M.; Wang, Y.C.; Chang, W.S.; Chang, Y.T.; Chen, W.Y.; Huang, C.Y.; Kuo, C.C.; et al. Recommendations and guidelines for the treatment of pneumonia in Taiwan. J. Microbiol. Immunol. Infect. 2019, 52, 172-199. [CrossRef]

9. Lee, J.Y.; Yang, P.C.; Chang, C.; Lin, I.T.; Ko, W.C.; Cia, C.T. Community-acquired adenoviral and pneumococcal pneumonia complicated by pulmonary aspergillosis in an immunocompetent adult. J. Microbiol. Immunol. Infect. 2019, 52, 838-839. [CrossRef]

10. Albrich, W.C.; Rassouli, F.; Waldeck, F.; Berger, C.; Baty, F. Influence of Older Age and Other Risk Factors on Pneumonia Hospitalization in Switzerland in the Pneumococcal Vaccine Era. Front. Med. 2019, 6, 286. [CrossRef]

11. Rothberg, M.B.; Haessler, S.D.; Brown, R.B. Complications of Viral Influenza. Am. J. Med. 2008, 121, 258-264. [CrossRef]

12. Feikin, D.R.; Schuchat, A.; Kolczak, M.; Barrett, N.L.; Harrison, L.H.; Lefkowitz, L.; McGeer, A.; Farley, M.M.; Vugia, D.J.; Lexau, C.; et al. Mortality from invasive pneumococcal pneumonia in the era of antibiotic resistance, 1995-1997. Am. J. Public Health 2000, 90, 223-229.

13. Huttner, B.; Cappello, B.; Cooke, G.; Gandra, S.; Harbarth, S.; Imi, M.; Loeb, M.; Mendelson, M.; Moja, L.; Pulcini, C.; et al. 2019 community-acquired pneumonia treatment guidelines: There is a need for a change toward more parsimonious antibiotic use. Am. J. Respir. Crit. Care Med. 2020, 201, 1315-1316. [CrossRef] [PubMed]

14. Bourouiba, L. Turbulent Gas Clouds and Respiratory Pathogen Emissions Potential Implications for Reducing Transmission of COVID-19. JAMA 2020, 323, 1837-1838.

15. Orenes-Piñero, E.; Baño, F.; Navas-Carrillo, D.; Moreno-Docón, A.; Marín, J.M.; Misiego, R.; Ramírez, P. Evidences of SARS-CoV-2 virus air transmission indoors using several untouched surfaces: A pilot study. Sci. Total Environ. 2021, 751, 142317. [CrossRef] [PubMed]

16. van Doremalen, N.; Bushmaker, T.; Morris, D.H.; Holbrook, M.G.; Gamble, A.; Williamson, B.N.; Tamin, A.; Harcourt, J.L.; Thornburg, N.J.; Gerber, S.I.; et al. Aerosol and Surface Stability of SARS-CoV-2 as Compared with SARS-CoV-1. N. Engl. J. Med. 2020, 382, 1564-1567. [CrossRef] [PubMed]

17. Ong, S.W.X.; Tan, Y.K.; Chia, P.Y.; Lee, T.H.; Ng, O.T.; Wong, M.S.Y.; Marimuthu, K. Air, Surface Environmental, and Personal Protective Equipment Contamination by Severe Acute Respiratory Syndrome Coronavirus 2 (SARS-CoV-2) from a Symptomatic Patient. JAMA J. Am. Med. Assoc. 2020, 323, 1610-1612. [CrossRef]

18. Chin, A.W.H.; Chu, J.T.S.; Perera, M.R.A.; Hui, K.P.Y.; Yen, H.-L.; Chan, M.C.W.; Peiris, M.; Poon, L.L.M. Stability of SARS-CoV-2 in different environmental conditions. Lancet Microbe 2020, 1, e10. [CrossRef]

19. Vellingiri, B.; Jayaramayya, K.; Iyer, M.; Narayanasamy, A.; Govindasamy, V.; Giridharan, B.; Ganesan, S.; Venugopal, A.; Venkatesan, D.; Ganesan, H.; et al. COVID-19: A promising cure for the global panic. Sci. Total Environ. 2020, $725,138277$. [CrossRef]

20. American Lung Association. American Lung Association Learn About Pneumonia. Available online: https://www.lung.org/ lung-health-diseases/lung-disease-lookup/pneumonia/learn-about-pneumonia (accessed on 2 January 2021).

21. Singhal, T. A Review of Coronavirus Disease-2019 (COVID-19). Indian J. Pediatr. 2020, 87, 281-286. [CrossRef] 
22. Bai, Y.; Yao, L.; Wei, T.; Tian, F.; Jin, D.Y.; Chen, L.; Wang, M. Presumed Asymptomatic Carrier Transmission of COVID-19. JAMA J. Am. Med. Assoc. 2020, 323, 1406-1407. [CrossRef]

23. Wang, L.; Didelot, X.; Yang, J.; Wong, G.; Shi, Y.; Liu, W.; Gao, G.F.; Bi, Y. Inference of person-to-person transmission of COVID-19 reveals hidden super-spreading events during the early outbreak phase. Nat. Commun. 2020, 11, 1-6.

24. Liu, Y.; Ning, Z.; Chen, Y.; Guo, M.; Liu, Y.; Gali, N.K.; Sun, L.; Duan, Y.; Cai, J.; Westerdahl, D.; et al. Aerodynamic analysis of SARS-CoV-2 in two Wuhan hospitals. Nature 2020, 582, 557-560. [CrossRef] [PubMed]

25. Richard, M.; Kok, A.; de Meulder, D.; Bestebroer, T.M.; Lamers, M.M.; Okba, N.M.A.; Fentener van Vlissingen, M.; Rockx, B.; Haagmans, B.L.; Koopmans, M.P.G.; et al. SARS-CoV-2 is transmitted via contact and via the air between ferrets. Nat. Commun. 2020, 11, 3496. [CrossRef] [PubMed]

26. Morawska, L.; Cao, J. Airborne transmission of SARS-CoV-2: The world should face the reality. Environ. Int. 2020, 139, 105730. [CrossRef] [PubMed]

27. Briz-Redón, Á.; Serrano-Aroca, Á. The effect of climate on the spread of the COVID-19 pandemic: A review of findings, and statistical and modelling techniques. Prog. Phys. Geogr. Earth Environ. 2020, 44, 591-604. [CrossRef]

28. Briz-Redón, Á.; Serrano-Aroca, Á. A spatio-temporal analysis for exploring the effect of temperature on COVID-19 early evolution in Spain. Sci. Total Environ. 2020, 728, 138811. [CrossRef]

29. Wu, Y.; Guo, C.; Tang, L.; Hong, Z.; Zhou, J.; Dong, X.; Yin, H.; Xiao, Q.; Tang, Y.; Qu, X.; et al. Prolonged presence of SARS-CoV-2 viral RNA in faecal samples. Lancet Gastroenterol. Hepatol. 2020, 5, 434-435. [CrossRef]

30. Baltimore, D. Expression of animal virus genomes. Bacteriol. Rev. 1971, 35, 235-241. [CrossRef]

31. Tuladhar, E.; de Koning, M.C.; Fundeanu, I.; Beumer, R.; Duizer, E. Different virucidal activities of hyperbranched quaternary ammonium coatings on poliovirus and influenza virus. Appl. Environ. Microbiol. 2012, 78, 2456-2458. [CrossRef]

32. Schrank, C.L.; Minbiole, K.P.C.; Wuest, W.M. Are Quaternary Ammonium Compounds, the Workhorse Disinfectants, Effective against Severe Acute Respiratory Syndrome-Coronavirus-2? ACS Infect. Dis. 2020, 6, 1553-1557. [CrossRef]

33. Kratzel, A.; Kratzel, A.; Todt, D.; V’kovski, P.; V'kovski, P.; Steiner, S.; Steiner, S.; Gultom, M.; Gultom, M.; Thao, T.T.N.; et al. Inactivation of Severe Acute Respiratory Syndrome Coronavirus 2 by WHO-Recommended Hand Rub Formulations and Alcohols. Available online: http://wwwnc.cdc.gov/eid/article/26/7/20-0915_article.htm (accessed on 20 November 2020).

34. Meister, T.L.; Brüggemann, Y.; Todt, D.; Conzelmann, C.; Müller, J.A.; Groß, R.; Münch, J.; Krawczyk, A.; Steinmann, J.; Steinmann, J.; et al. Virucidal Efficacy of Different Oral Rinses Against Severe Acute Respiratory Syndrome Coronavirus 2. J. Infect. Dis. 2020, 222, 1289-1292. [CrossRef]

35. Pannu, J.; Ciotti, S.; Ganesan, S.; Arida, G.; Costley, C.; Affiliations, A. Nanodroplet-Benzalkonium Chloride Formulation Demonstrates In Vitro and Ex-Vivo Broad-Spectrum Antiviral Activity Against SARS-CoV-2 and other Enveloped Viruses Broad-Spectrum Antiviral Activity of Nanodroplet-BZK Key Words Antiviral, Nanoemulsion, Nanodr. bioRxiv 2020. [CrossRef]

36. El-Ghazzawy, A.G.; Gupta, N.; Swope, T.J.; Kulkarni, A.D.; Panneton, W.M.; Robinson, S.M.; Niehoff, M.L.; Kaminski, D.L.; Andrus, C.H. Evaluation of benzalkonium chloride chemoneurolytic proximal gastric vagotomy. Surg. Endosc. 1998, 12, 207-211. [CrossRef] [PubMed]

37. Leung, N.H.L.; Chu, D.K.W.; Shiu, E.Y.C.; Chan, K.H.; McDevitt, J.J.; Hau, B.J.P.; Yen, H.L.; Li, Y.; Ip, D.K.M.; Peiris, J.S.M.; et al. Respiratory virus shedding in exhaled breath and efficacy of face masks. Nat. Med. 2020, 26, 676-680. [CrossRef] [PubMed]

38. De Maio, F.; Palmieri, V.; Babini, G.; Augello, A.; Palucci, I.; Perini, G.; Salustri, A.; De Spirito, M.; Sanguinetti, M.; Delogu, G.; et al. Graphene nanoplatelet and Graphene oxide functionalization of face mask materials inhibits infectivity of trapped SARS-CoV-2. medRxiv 2020. [CrossRef]

39. Kumar, S.; Karmacharya, M.; Joshi, S.R.; Gulenko, O.; Park, J.; Kim, G.-H.; Cho, Y.-K. Photoactive Antiviral Face Mask with Self-Sterilization and Reusability. Nano Lett. 2020. [CrossRef]

40. Tremiliosi, G.; Simoes, L.G.; Minozzi, D.; Santos, R.; Vilela, D.; Durigon, E.L.; Machado, R.R.G.; Medina, D.S.; Ribeiro, L.K.; Rosa, I.L.V.; et al. Ag nanoparticles-based antimicrobial polycotton fabrics to prevent the transmission and spread of SARS-CoV-2. bioRxiv 2020. [CrossRef]

41. Zhang, J.; Li, B.; Wu, L.; Wang, A. Facile preparation of durable and robust superhydrophobic textiles by dip coating in nanocomposite solution of organosilanes. Chem. Commun. 2013, 49, 11509-11511. [CrossRef]

42. Das, O.; Neisiany, R.E.; Capezza, A.J.; Hedenqvist, M.S.; Försth, M.; Xu, Q.; Jiang, L.; Ji, D.; Ramakrishna, S. The need for fully bio-based facemasks to counter coronavirus outbreaks: A perspective. Sci. Total Environ. 2020, 736, 139611. [CrossRef]

43. Pelosini, L.; Treffene, S.; Hollick, E.J. Antibacterial activity of preservative-free topical anesthetic drops in current use in ophthalmology departments. Cornea 2009, 28, 58-61. [CrossRef]

44. WHO. WHO Antibiotic Resistance. Available online: https://www.who.int/health-topics/antimicrobial-resistance (accessed on 2 January 2021).

45. Wade, K.C.; Benjamin, D.K. Clinical Pharmacology of Anti-Infective Drugs. In Infectious Diseases of the Fetus and Newborn Infant; Elsevier: Amsterdam, The Netherlands, 2011; pp. 1160-1211.

46. Lee, J.Y.H.; Monk, I.R.; Gonçalves da Silva, A.; Seemann, T.; Chua, K.Y.L.; Kearns, A.; Hill, R.; Woodford, N.; Bartels, M.D.; Strommenger, B.; et al. Global spread of three multidrug-resistant lineages of Staphylococcus epidermidis. Nat. Microbiol. 2018, 3, 1175-1185. [CrossRef]

47. Lakhundi, S.; Zhang, K. Methicillin-Resistant Staphylococcus aureus: Molecular Characterization, Evolution, and Epidemiology. Clin. Microbiol. Rev. 2018, 31, e00020-18. [CrossRef] [PubMed] 
48. Chessa, D.; Ganau, G.; Spiga, L.; Bulla, A.; Mazzarello, V.; Campus, G.V.; Rubino, S. Staphylococcus aureus and Staphylococcus epidermidis Virulence Strains as Causative Agents of Persistent Infections in Breast Implants. PLoS ONE 2016, 11, e0146668. [CrossRef] [PubMed]

49. Kropinski, A.M.; Mazzocco, A.; Waddell, T.E.; Lingohr, E.; Johnson, R.P. Enumeration of bacteriophages by double agar overlay plaque assay. Methods Mol. Biol. 2009, 501, 69-76. [PubMed]

50. Matsuyama, S.; Nao, N.; Shirato, K.; Kawase, M.; Saito, S.; Takayama, I.; Nagata, N.; Sekizuka, T.; Katoh, H.; Kato, F.; et al. Enhanced isolation of SARS-CoV-2 by TMPRSS2- expressing cells. Proc. Natl. Acad. Sci. USA 2020, 117, 7001-7003. [CrossRef]

51. Martí, M.; Frígols, B.; Serrano-Aroca, Á. Antimicrobial Characterization of Advanced Materials for Bioengineering Applications. J. Vis. Exp. 2018, e57710. [CrossRef]

52. Shao, W.; Liu, H.; Liu, X.; Wang, S.; Wu, J.; Zhang, R.; Min, H.; Huang, M. Development of silver sulfadiazine loaded bacterial cellulose/sodium alginate composite films with enhanced antibacterial property. Carbohydr. Polym. 2015, 132, 351-358. [CrossRef]

53. Gill, S.R.; Fouts, D.E.; Archer, G.L.; Mongodin, E.F.; DeBoy, R.T.; Ravel, J.; Paulsen, I.T.; Kolonay, J.F.; Brinkac, L.; Beanan, M.; et al. Insights on evolution of virulence and resistance from the complete genome analysis of an early methicillin-resistant Staphylococcus aureus strain and a biofilm-producing methicillin-resistant Staphylococcus epidermidis strain. J. Bacteriol. 2005, 187, 2426-2438. [CrossRef]

54. Christensen, G.D.; Bisno, A.L.; Parisi, J.T.; McLaughlin, B.; Hester, M.G.; Luther, R.W. Nosocomial septicemia due to multiply antibiotic-resistant Staphylococcus epidermidis. Ann. Intern. Med. 1982, 96, 1-10. [CrossRef]

55. Hora, P.I.; Pati, S.G.; McNamara, P.J.; Arnold, W.A. Increased Use of Quaternary Ammonium Compounds during the SARS-CoV-2 Pandemic and Beyond: Consideration of Environmental Implications. Environ. Sci. Technol. Lett. 2020, 7, 622-631. [CrossRef]

56. Yamanaka, T.; Bannai, H.; Tsujimura, K.; Nemoto, M.; Kondo, T.; Matsumura, T. Comparison of the virucidal effects of disinfectant agents against equine influenza a virus. J. Equine Vet. Sci. 2014, 34, 715-718. [CrossRef]

57. Gerba, C.P. Quaternary ammonium biocides: Efficacy in application. Appl. Environ. Microbiol. 2015, 81, 464-469. [CrossRef] [PubMed]

58. Neacşu, I.A.; Nicoară, A.I.; Vasile, O.R.; Vasile, B.Ş. Inorganic micro- and nanostructured implants for tissue engineering. In Nanobiomaterials in Hard Tissue Engineering: Applications of Nanobiomaterials; Elsevier Inc.: Amsterdam, The Netherlands, 2016; pp. 271-295. 